DOI: https://doi.org/10.31933/dijemss.v3i2 Received: 15 November 2021, Revised: 25 December 2021, Publish: 18 January 2022

\begin{tabular}{|c|c|c|}
\hline DINASTI & $\begin{array}{l}\text { DIJEMSS } \\
\text { DINASTI INTERNATIONAL JOURNAL } \\
\text { OF EDUCATION MANAGEMENT AND } \\
\text { SOCIAL SCIENCE }\end{array}$ & $\begin{array}{r}\text { https://dinastipub.org/DIJEMSS } \\
\text { editor@dinastipub.org } \\
08117401455 \text { (W }\end{array}$ \\
\hline
\end{tabular}

\title{
EFFECT OF WORK ENVIRONMENT ON EMPLOYEE PERFORMANCE THROUGH MOTIVATION AT STARBUCKS COFFEE CIBUBUR BRANCH
}

\author{
Eddy Sanusi Silitonga ${ }^{1}$ \\ ${ }^{1}$ Lecturer of the Economics Faculty UNKRIS Management Study Program, UNKRIS \\ Campus, Jatiwaringin, East Jakarta, eddy.sanusi23@gmail.com
}

Corresponding Author: Eddy Sanusi Silitonga

\begin{abstract}
This study aims to determine the performance of existing employees at Starbucks Coffee Cibubur Branch is influenced by the work environment through Motivation. This research was conducted on employees of the Starbucks Coffee Cibubur Branch. The research method used in this study is a data collection method used by distributing questionnaires to respondents or employees. This study uses the method of total sampling, or saturated sampling, where the sample used is all population members. The results of this study indicate that the work environment does not affect employee performance. Motivation affects employee performance. The work environment affects Motivation, and employee performance affects the work environment through Motivation. With these results,
\end{abstract}

Keywords: Work environment, Motivation, and employee performance

\section{INTRODUCTION}

Employee performance, in general, is one of the main parts of an organization or company because the benefits are proven to be very crucial; an organization wants employees to work seriously with the performance capabilities possessed to get good work results, if you do not have good work performance from individual employees, then success in getting the goals and targets set will be challenging to achieve. Its core performance includes mental attitude and behavior that always believes that the work being carried out today must be of higher quality than the implementation of the previous work. An employee will feel pride and satisfaction by making contributions and achievements based on the performance he has given to the company. Good performance is a desirable state in the world of work. If an employee wants to get good work performance, he must carry out standard procedures that apply within the company, both in quality and quantity.

The understanding of performance or performance shows the achievement of performance in implementing an action or policy program to achieve the organization's goals, objectives, vision, and mission as stated in the strategic plan of the organization. 
Every company must have a goal that must be achieved when carrying out its activities, and to achieve or realize these goals, every company must be able to choose its management skills, especially its human resource plan, which focuses on certain phases. Affandi (2018) suggests that performance is the result of work that can be achieved by a person or group of people in a company following their respective authorities and responsibilities to achieve organizational goals illegally, not violating the law, and not contrary to morals and ethics. With the increasingly competitive world of work, the world of work can continue to increase its productivity to achieve the goal of generating multiple incomes (profits) and benefiting society. To achieve the company's goals, we need a qualified workforce following the required fields selectively. Human resources are the main factor for a company because they are active players.

To improve the performance of good employees, environmental factors are also very influential; employee performance will increase along with the influence of aspects of the work environment. Aspects of the work environment that have a significant influence, namely the condition of the physical work environment and the non-physical work environment, these two work environment conditions are interconnected and balanced with each other, which aims to provoke employees to work productively, according to Sedarmayanti (2017), a work environment is a place that can affect an employee's performance because a human will be able to carry out activities well so that an optimal result is achieved if an appropriate environmental condition is shown.

According to previous research by Umam (2016), Wungkana (2015), Krisnayanti (2018), Ramadhani (2014), and Adrianto (2020)concluded that a comfortable and conducive work environment will optimize employee performance. In addition to the need for a good work environment, employees also need Motivation from themselves and from outside to improve performance because sometimes a sense of laziness in employees can threaten their careers. After all, the company may give a warning or even layoffs. Laziness arises because employees often feel unable to do their jobs well, so they feel insecure and feel lazy at work. This is a big problem for the company, so the provision of training and Motivation is an excellent effort to improve employee performance.

Motivation is a driving force within a person's heart to do or achieve a goal. Motivation can also be referred to as a plan or desire to succeed and avoid failure. In other words, Motivation is the process of achieving a goal. Motivation can be formulated as a condition or behavior that encourages an individual to do as many things or activities as possible to act and produce. According to Afandi (2018), Motivation is a desire that arises from a person or individual because he is inspired, encouraged, and driven to carry out activities with sincerity, pleasure, and sincerity. The results of the activities carried out get quality results. The role of Motivation in the company should not be underestimated. Appropriate application of Motivation can help motivate employees to initiate support activities, and in general, help efforts to achieve company goals. Motivation provides enormous overall benefits for employee performance. Motivation has great benefits 
holistically on the overall performance of employees. Previous research by Hidayat (2015), Alamdani (2020), Sukadi (2021), and Badrianto (2019) concluded that the higher the level of Motivation, such as giving praise for work, bonuses, and appropriate compensation, the higher the quality of the employee's work.

This study aimed to determine the performance of Starbucks Coffee Cibubur Branch employees influenced by the work environment through Motivation.

\section{LITERATURE REVIEW}

\section{Employee performance}

In order for an organization or company to develop and progress, there must be quality standards for its employees, and so that employees can achieve good performance, they must ensure their performance is following predetermined company standards.Afandi(2018) suggests that performance is the result of work that can be achieved by a person or group in a company following their respective authorities and responsibilities to achieve organizational goals illegally, not violating the law and not contradicting morals and ethics, because a company requires Good employee performance is following what is responsibilities so that the achievement of organizational goals usually goes according to predetermined targets. In addition, performance is an ability that every employee must have; as explained bySinambela, (2018), they provide an opinion about employee performance, which is the ability of employees to perform specific skills. Being an employee means not only doing what the boss tells you to do but also providing ideas for developing the company by using the skills you have.

Next, Kasmir (2016) says that performance is the result and work behavior that has been achieved in completing the tasks and responsibilities given within a certain period. In that case, good performance is the result achieved and refers to achieving and implementing a requested job. However, good behavior to carry out a work activity aims to produce quality and quantity in work. While according toMoeheriono (2012) conclude about the notion of employee performance, namely performance or performance is a description of the level of achievement achieved in the implementation of an activity or policy program that realizes the goals, objectives, vision, and mission of the organization as outlined in the company's strategic plan. Without goals or tasks, we cannot know the performance of a person or organization because there are no standards. In this case, the performance of each individual or group must be taken into account to achieve the goals that have been set. Depends on strategy and vision, and mission. The term performance is often used to refer to the level of achievement or success of individuals, and performance is only known if the group has established success criteria.

Based on the understanding of performance from some of these opinions, it can be concluded that performance is the result of qualitative and quantitative work carried out by employees in carrying out their work following the responsibilities given by the company, and the work achieved is in line with employee productivity. 
Some of the factors that can affect employee performance according to cashmere (2016): 1) Ability and skills; An ability or skill that a person has at work. 2) Knowledge; Someone who is experienced in work to achieve good results in work. 3) Job Design; make it easier for employees to achieve their goals. 4) Personality; The character or personality of the employee. 5) Work Motivation; A person's encouragement to try hard to get maximum results. 6) Leadership; The leader's actions in organizing, managing, and directing subordinates to carry out the tasks and responsibilities given. 7) Leadership Style; the way a leader manages his subordinates. 8) Organizational Culture; Habits or norms that an organization or company applies. 9) Job Satisfaction; Feelings of satisfaction or pleasure after doing work. 10) Work Environment; The atmosphere or conditions of the workplace. 11) Loyalty; Loyalty to keep working and defend the company where he works. 12) Commitment; Employee engagement to enforce company policies or regulations. 13) Work Discipline; Carry out work activities following the specified time

The indicators used in this research adopt the theory stated by Affandi(2018) Performance indicators also; performance indicators are also defined as measuring tools used to determine the level of success of the organization in achieving its goals, following indicators that affect employee performance appraisal, namely: 1) Quality of work results; All kinds of units of measure related to the quality or quality of work that can be stated in numerical measures or other numerical guidelines. 2) Quantity of work; All kinds of units of measure that relate to the amount of work expressed in numbers or other numerical equivalents. 3) Honesty; One of human nature that is quite difficult to apply. 4) Work discipline; Comply with operational standards, applicable laws, and regulations. 5) Efficiency in carrying out tasks; Various human resources wisely and in a cost-saving manner. 6) Initiative; The ability to make snap decisions and do the right thing, the ability to know what to do with what is around, and the ability to keep moving on doing things even when the going gets more challenging. 7) Accuracy; The level of conformity of the work measurement results whether the work has been completed with the specified target or not. 8) Creativity; A mental process that generates ideas that affect the development of a company. 9) Leadership; Influencing or leading by example to followers in achieving organizational goals. The ability to know what to do with what is around and keep moving on doing something even when the going gets more challenging. 7) Accuracy; The level of conformity of the work measurement results whether the work has been completed with the specified target or not. 8) Creativity; A mental process that generates ideas that affect the development of a company. 9) Leadership; Influencing or leading by example to followers in achieving organizational goals. The ability to know what to do with what is around and keep moving on doing something even when the going gets more challenging. 7) Accuracy; The level of conformity of the work measurement results whether the work has been completed with the specified target or not. 8) Creativity; A mental process that generates ideas that affect the development of a company. 9) Leadership; Influencing or leading by example to followers in achieving organizational goals. A mental process that generates ideas that affect the development of a company. 9) Leadership; Influencing or 
leading by example to followers in achieving organizational goals. A mental process that generates ideas that affect the development of a company. 9) Leadership; Influencing or leading by example to followers in achieving organizational goals.

\section{Work environment}

The work environment in practice, the management of a company, must use a good management pattern, good management in carrying out work, one of which can be through the management of the work environment and of course an employee wants a work environment that is suitable and supportive and must be able to have a good impact on employees at work, according to Sedarmayanti (2017) a work environment is a place where people can work well, which can affect employee performance and provide optimal results when the proper environmental conditions are presented. A good environment is to create conditions that employees feel. An appropriate work environment where employees can feel satisfied at work and good work environment management and work support facilities must also be considered. Management can see the work environment because good working conditions are proven to speed up the completion of work. However, apart from the building that we pay attention to, the workspace and work tools must also be in good condition so that work activities can run smoothly and comfortably.

Meanwhile, according to Afandi(2018), the work environment is a worker's environment that can affect performance when performing tasks such as temperature, humidity, ventilation, lighting, noise, cleanliness of the workplace, and compliance with work requirements and equipment. These factors need to be considered for comfort and safety in carrying out work productivity. A good work environment is an important aspect to influence employee attitudes and Motivation such asSunyoto (2015) said, the work environment is an essential component because a good work environment and complete facilities minimize the possibility of work accidents that can harm individuals, businesses, or organizations. Hence, a good work environment for employees is essential to improve performance. A good work environment supported and managed correctly will make daily work feel comfortable and safe.

From some of these opinions, it can be concluded that the work environment, both physical and non-physical, can affect their daily duties and responsibilities. Employees perform well for optimal results when supported by appropriate environmental conditions, and when environmental conditions are conducive or deemed appropriate, employees can carry out their activities in an optimal, healthy, safe, and comfortable manner. Sedarmayanti (2017) several factors that can affect the formation of a working environment condition associated with human/employee abilities, including 1) Lighting/lighting in the workplace; Light and lighting are instrumental for employees to ensure safety and smooth work, so it is necessary to pay attention to good and not dazzling lighting. 2) Temperature/air temperature in the workplace; Under normal circumstances, every member of the human body has a different temperature. The human body always tries to maintain a normal state, with a perfect body system that can adapt to changes 
outside the body. 3) Humidity in the workplace; humidity in the air, usually expressed as a percentage. This humidity is related to or depends on the air temperature, and humidity, the speed of air movement, and thermal radiation from the air can affect the state of the body when receiving or releasing heat from the body. 4) Air circulation in the workplace; Oxygen is a gas needed by living things to maintain life, namely for metabolic processes. The air around is dirty when the oxygen level in the air has decreased and is mixed with gases and odors that are harmful to the health of the body. 5) Noise in the workplace; One of the pollutions that are quite busy for experts to overcome is noise, which is not desired by the ear. Not desirable, because especially in the long term, the sound can disturb the peace of work, damage hearing, and cause communication errors, even according to research, Serious noise can cause death. 6) Mechanical vibration at work; Mechanical vibration means vibration caused by a mechanical device, which reaches the employee's body and can cause unwanted effects. Mechanical vibrations are disturbing to the body because of their irregularity, both irregular in intensity and frequency. 7) Bad smell in the workplace; odors around the workplace can be considered as pollution because they can interfere with concentration at work, and odors that occur continuously can affect olfactory sensitivity. The use of the right air conditioner is a way that can be used to eliminate annoying odors around the workplace. 8) Coloring in the workplace; Color management in the workplace needs to be studied and planned as well as possible. The color scheme cannot be separated from the decoration arrangement. This is understandable because color has a significant influence on feelings. 9) Decoration in the workplace; Decoration has to do with good color planning. Therefore, decoration is related to the decoration of the workspace and has to do with how to arrange the layout, colors, equipment, and others for work. 10) Music at work; According to experts, soft music can arouse and stimulate employees to work according to the atmosphere, time, and place. 11) Safety at work; To keep the place and conditions of the work environment safe, it is necessary to pay attention to safety at work.

According to Sedarmayanti (2017), regarding the physical work environment, namely all physical environmental conditions that exist around the workplace that can affect employees both directly and indirectly, while the non-physical work environment is all circumstances that occur related to relationships with co-workers or relationships with subordinates. . The following are indicators of the work environment: 1) Physical work environment. 2) Non-physical work environment.

\section{Motivation}

Motivation is a will or desire that arises in employees that creates enthusiasm or encouragement to work optimally in order to achieve goals, such as the understanding of Motivation according to Afandi (2018), is a desire that arises from within a person or individual because he is inspired, encouraged, and driven to carry out activities with sincerity, pleasure, and sincerity so that the results of the activities carried out get good and quality results. Giving the right Motivation will lead to enthusiasm, willingness, and sincerity to work. Increasing enthusiasm and willingness to work sincerely will make work 
more optimal to increase work productivity and get perfect results. Motivation must be given to employees to increase enthusiasm for work. Therefore Motivation must be appropriate to what someone needsHasibuan(2016) stated that Motivation is a stimulant of desire and a driving force of one's willingness to work. Each motive has a specific goal to be achieved because Motivation is a mental force oriented towards fulfilling expectations and achieving goals.

Moreover, goals are goals or things to be achieved by an individual. Motivation is a source of strength to raise oneself from all problems such asWinardi (2016) say that Motivation is a potential force that exists within a human being, which can be developed by himself or developed by several outside forces which essentially revolves around monetary rewards and non-monetary rewards that can positively or negatively affect performance results. Work motivation is needed as a supplier of energy for activities during work which makes a person understand the organization's alignment to get better performance results.

Motivation can be generated, developed, and strengthened by processes and factors influencing a person. Farida (2016) stated that Motivation is the thing that causes, distributes, and supports human behavior so that you want to work hard and enthusiastically to achieve optimal results. Because Motivation is a driving force that can create a person's passion for work so that they want to work effectively and with integrity with all their power to achieve satisfaction, for this reason, Motivation is a condition that can move humans towards a particular goal, such as Robbins (2015) conclude that Motivation is a process that describes a person's strength, direction, and persistence to achieve a goal. Motivation is a mental attitude and human condition that provides energy and moves/channels behavior to achieve satisfying needs.

Based on these opinions, Motivation is a condition that moves people and creates enthusiasm or work urge to do the work they want willingly and without coercion to follow their duties and responsibilities.

A company needs to improve and maintain its employee's performance to stay active and achieve company goals. Before explaining some theories of Motivation, experts put forward some theories of Motivation: 1)Hierarchy Theory; The theory of Motivation developed by Maslow explains the hierarchical arrangement of human needs from the lowest level to the highest level. This hierarchy of needs can be seen in the image below.

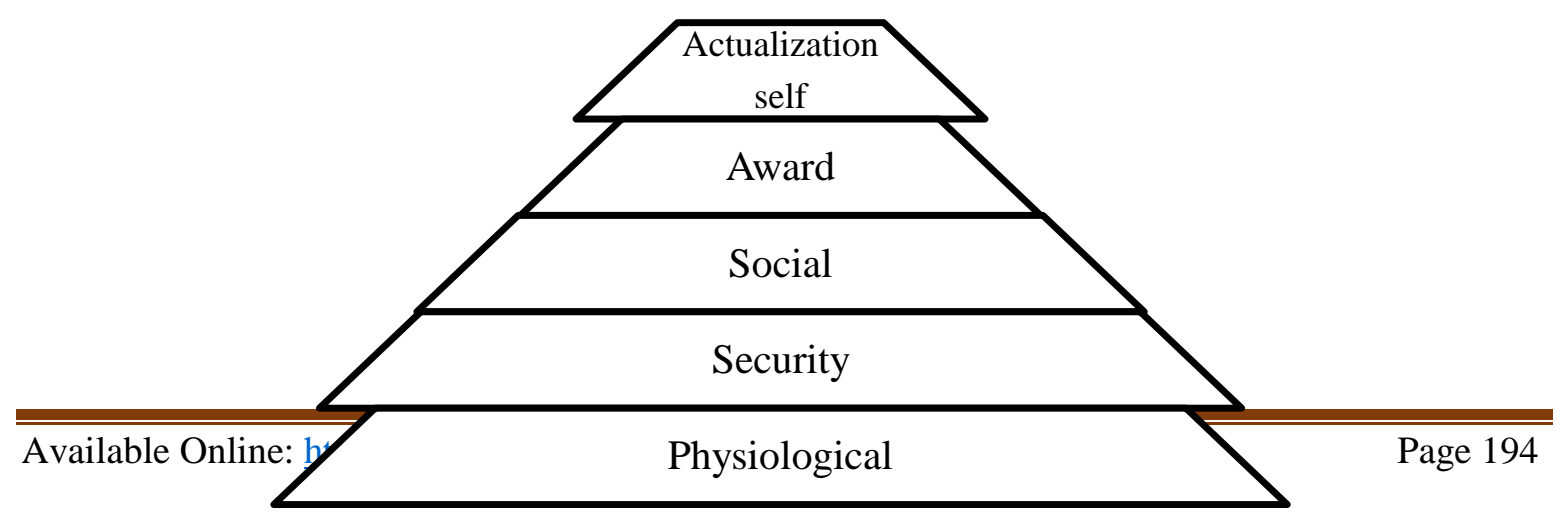




\section{Figure 2.1 Maslow's Hierarchy of Needs}

Source: Luthas (2010)

Based on the picture can be explained as follows: a). Physiological Needs; The most basic needs that an individual must meet. These needs are in the form of clothing, food, and shelter. For example, food, drink, accommodation, salary, rest time, health insurance, work environment, accommodation. b). Security Needs; This requirement is fulfilled after the initial requirements have been met. In general, people want to be protected and safe and not in danger. c). Social Needs; The need to feel recognized is the need for group acceptance, association, interaction, and the need to be loved. d). Appreciation Needs; This need includes the desire for self-esteem. These needs are usually individuals who want to show their success and want others to appreciate their success. e). Self-Actualization Needs; Represents the need to use skills, abilities, and needs. To discuss and express opinions, critique ideas, and others. Maslow's Theory of the Hierarchy of Desires is one of the theories that has succeeded in explaining the desires of the five levels, and each level will be achieved as the previous level is gradually surpassed. Maslow's thoughts on needle theory sound theoretical, but they provide a lot of background and inspiration for motivation theory developers who want to apply them further, including the HR management I have done. 2) Douglas McGregor's theory (X and Y); Theory X (conventional theory), in which human characteristics are described as lazy individuals, irresponsible and do not like to work and irresponsible individuals, theory Y (Potential theory), where humans are described as diligent individuals, like work, have responsibilities. a). In theory, $\mathrm{X}$ tends to be the following types of people: (1) Irresponsible. (2) Avoiding responsibility. (3) I hate work. (4) I like to work under supervision and cannot solve big or small problems independently. b). In theory, Y tends to be the following type of person: (1) Productive and ambitious. (2) Make the right decision. (3) always want to change lives and have the courage to do new things. $X$ tends to be the following types of people: (1) Irresponsible. (2) Avoiding responsibility. (3) I hate work. (4) I like to work under supervision and cannot solve big or small problems independently. b). In theory, Y tends to be the following type of person: (1) Productive and ambitious. (2) Make the right decision. (3) always want to change lives and have the courage to do new things. $X$ tends to be the following types of people: (1) Irresponsible. (2) Avoiding responsibility. (3) I hate work. (4) I like to work under supervision and cannot solve big or small problems independently. b). In theory, $\mathrm{Y}$ tends to be the following type of person: (1) Productive and ambitious. (2) Make the right decision. (3) always want to change lives and have the courage to do new things.

According to Afandi (2018), Motivation is a factor that encourages someone to carry out a particular activity; here are some indicators of Motivation, namely as follows: 1) Retribution; Everything in the form of goods, services, and money which is the compensation received by employees for their services involved in the organization. 2) Working conditions; The condition or state of a company's work environment that is a place of work for employees who work in that environment. Good working conditions are 
comfortable and support workers to carry out their activities well. 3) work facilities; Everything in the organization is occupied and enjoyed by employees, both in direct relation to work and for the smooth running of work. 4) work performance; Results achieved or desired by everyone at work. Each person is not the same size because humans are different. 5) Recognition from superiors; A statement was given from the superior whether the employee has applied the motivation given.

\section{RESEARCH METHODS}

This research was conducted on employees of the Starbucks Coffee Cibubur Branch. The research method used in this study is a data collection method used by distributing questionnaires to respondents or employees. This study uses the method of total sampling or sampling saturated where the sample used is all population members. Before testing the model, the validity and reliability were tested first, the analysis method using path analysis. (Sarwono, 2010)

\section{FINDINGS AND DISCUSSION}

\section{Test Instrument Data}

Based on this description, to determine whether the work environment and motivation variables can be used as a measure of employee performance Starbucks Coffee Cibubur Branch. However, before that, the data was processed first and tested on the variables used, namely the work environment, Motivation, and employee performance, to determine whether the data was accurate and reliable.

\section{Validity test}

This validity test is carried out to test whether each statement item represents the indicator to be studied; the minimum requirement to be said to be valid is $r=0.30$. So, if the correlation between the statement items with the total score is less than 0.30 , then the items in the instrument can be said to be invalid. The validity test was carried out by looking at the correlation between the scores of each statement item and the total score. (Sugiyono, 2018).

\section{Variable Instrument Validity Test}

From the calculation of the correlation coefficient score for each statement item from 50 respondents about the work environment instrument, with a total of 6 statements; motivation instrument ten statements and employee performance instrument 18 statements with a total score of each respondent obtained the results of $r$ count greater than $r$ critical of 0.300 .

\section{Reliability Test}

This reliability test is carried out to test how far the measurement results are consistently reliable. For example, in the test results table following reliability, it is known 
that all variables have an alpha above 0.6 which means that all variables in this study are reliable

Table 1: Variable Reliability Test Results

\begin{tabular}{lcc}
\hline \multicolumn{1}{c}{ Variable } & Cronbach's Alpha & Description \\
\hline Work environment & 0.828 & Reliable \\
Motivation & 0.949 & Reliable \\
Employee performance & 0855 & Reliable \\
\hline Source: Data processing results, 2021 & &
\end{tabular}

Based on Table 1, it can be concluded that the Cronbach's Alpha value is positive, more significant than 0.6 , which is the minimum limit of the reliability coefficient that can be considered reasonable. And reliable.

\section{Path Analysis}

The method used in this study is path analysis because it aims to explain the direct and indirect effects between the independent variable and the dependent variable.

\section{Model 1}

Table 2: Model 1

\begin{tabular}{lccccccc}
\hline \multirow{2}{*}{ Variable } & R Square & constant & $\begin{array}{c}\text { Regression } \\
\text { Coefficient }\end{array}$ & Beta & Sig & $\square$ \\
\cline { 2 - 7 } & 0.785 & 35,978 & 0.433 & 0.179 & 0.139 & 0.05 \\
\hline Work environment & & 0.599 & 0.733 & 0.000 & \\
motivation & & & &
\end{tabular}

Description: Employee_Performance Variable

Source: data processed 2021

Based on table 2, the path value (standardized coefficients beta) obtained a significant value for the work environment of Sig $0.139>0.05$, which indicates that the work environment has no significant effect on employee performance. The results of the motivation analysis show the value of Sig. $0.000<0.05$, which indicates a significant effect of Motivation on employee performance.

The R Square value of 0.785 shows that the contribution of the work environment and Motivation to employee performance is $78.5 \%$, while the other $21.5 \%$ is the contribution of variables not examined in this study. Meanwhile, the value of e1 can be found with the formula $\mathrm{e} 1=\sqrt{ }(1-0.785)=0.463$. Thus, the path diagram of the structure model 1 is obtained as follow

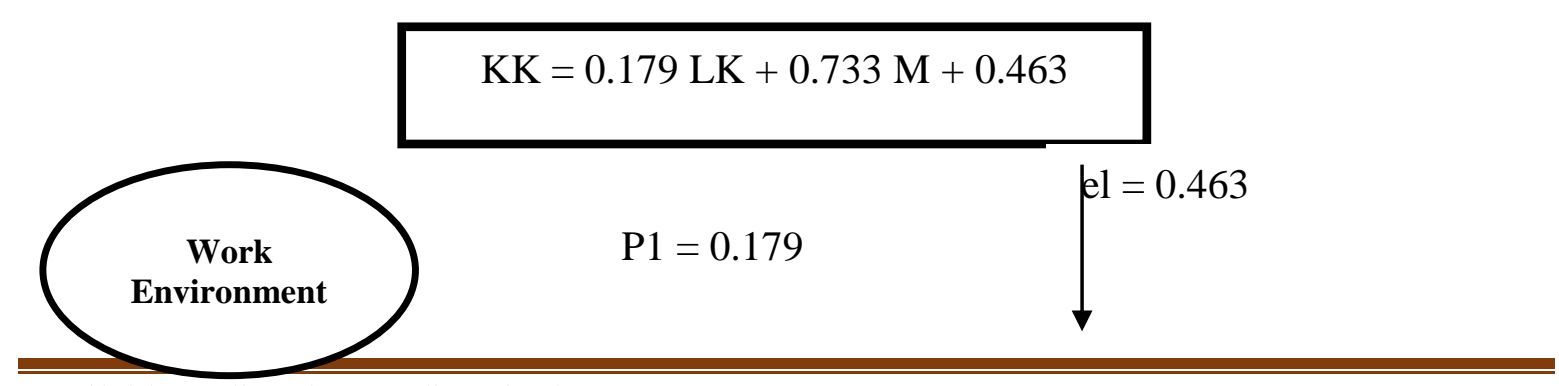




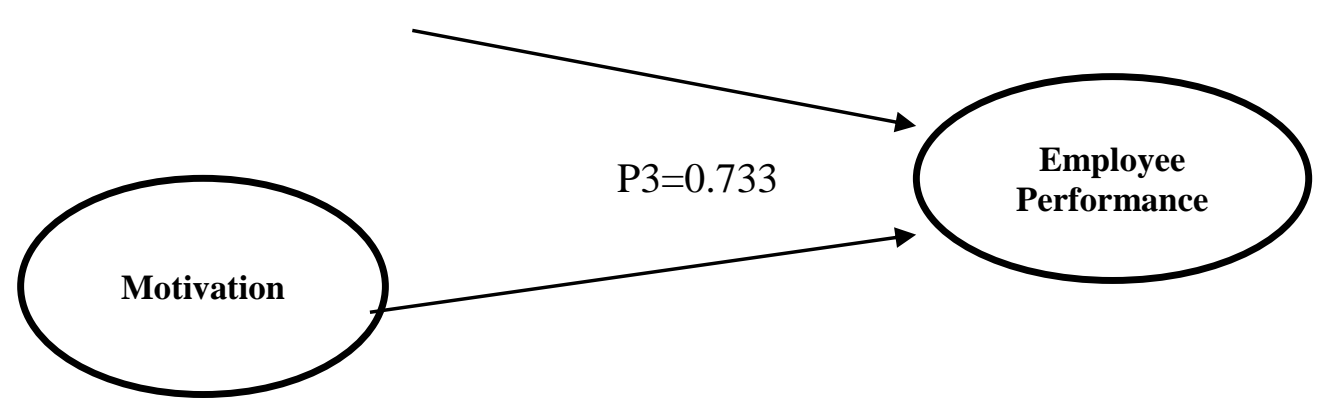

Figure 1: Results of Path Analysis Model 1

Model 2

Table 3: Model 2

\begin{tabular}{ccccccc}
\hline \multirow{2}{*}{ Variable } & R Square & constant & $\begin{array}{c}\text { Regression } \\
\text { Coefficient }\end{array}$ & Beta & Sig & $\square$ \\
\cline { 2 - 7 } & 0.677 & $-19,854$ & 2,436 & 0.823 & 0.000 & 0.05 \\
\hline Work environment & 0.0036
\end{tabular}

Description: Employee_Performance Variable

Source: data processed 2021

Based on table 3, the path value results (standardized coefficients beta) obtained a significant value for the work environment of $0.000<0.05$, which indicates that the work environment has a significant effect on Motivation. The R Square value of 0.677 shows that the contribution of the work environment to Motivation is $67.7 \%$, while the other $32.3 \%$ is the contribution of variables not examined in this study. Meanwhile, the value of e 2 can be found with the formula $\mathrm{e} 2=\sqrt{ }(1-0.677)=0.568$. Thus, the path diagram of the substructure model 1 is obtained as follows:

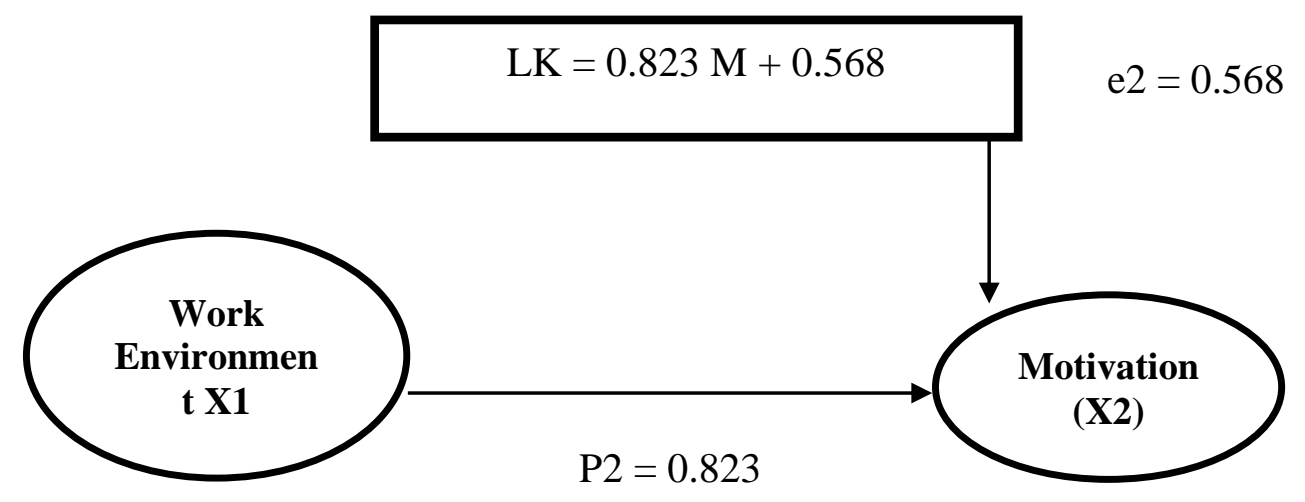

Figure 2: Results of Path Analysis Model 2

Model 3

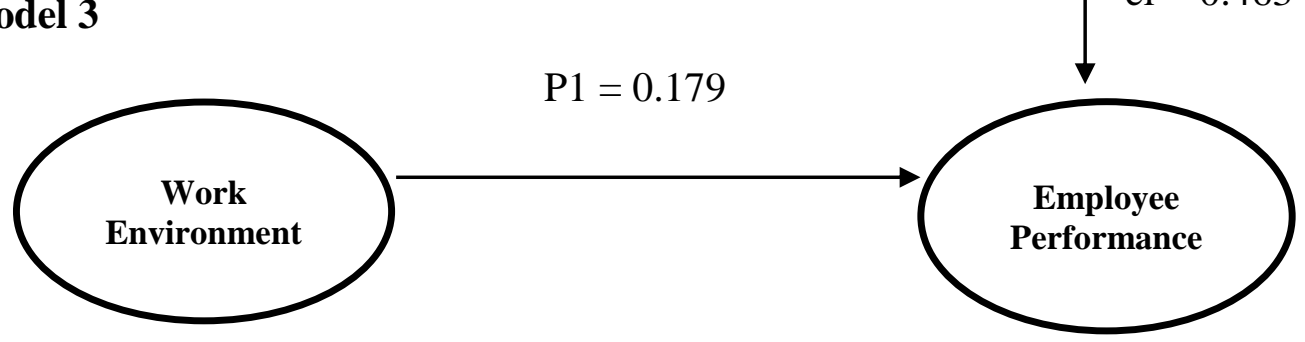




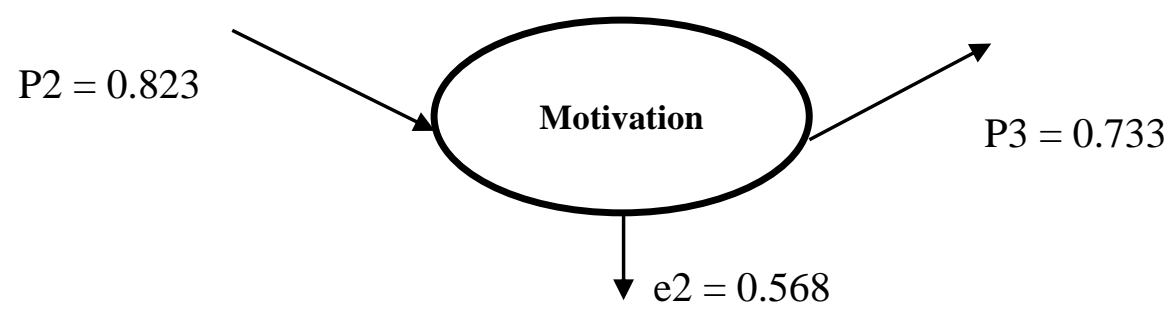

Figure 2: Results of Path Analysis Model 3

\section{Hypothesis Test Results}

\section{Hypothesis Testing 1}

Work Environment does not affect employee performance at Starbucks Coffee Cibubur.

The study results between the work environment and employee performance obtained similarities between the work environment variables on employee performance and the results.

$$
\mathrm{Y}=0.179 \mathrm{LK}+0.463
$$

This result is a path one analysis model, the work environment contributes 0.179 to the employee's performance, and the error in the work environment to the employee's performance is 0.463 .

\section{Hypothesis Testing 2}

Motivation affects employee performance at Starbucks Coffee Cibubur Branch.

The study results between Motivation and employee performance obtained similarities between Motivation on employee performance and results.

$$
\mathrm{Y}=0.733 \mathrm{M}+0.463 \text {. }
$$

The result is a path analysis model 2, Motivation to employee performance contributes 0.733 , and the error results in Motivation to employee performance is 0.463 .

\section{Hypothesis Testing 3}

Work Environment Affects Employee Work Motivation Starbucks Coffee Cibubur Branch

The results of research between work environment and Motivation obtained similarities between work environment on Motivation and results.

$$
\mathrm{X} 2=0.823 \mathrm{X} 1+0,568
$$


The result is a path three analysis model; the work environment contributes to the Motivation that is equal to 0.823 , and for the results of the error in the work environment to the Motivation that is equal to 0.568 .

\section{Hypothesis Testing 4}

The Effect of Mediation on Motivation on the Work Environment With Employee Performance Starbucks Coffee Cibubur Branch

The magnitude of the direct influence given by the work environment on the performance of employees at Starbucks Coffee Cibubur is 0.179, and the magnitude of the indirect effect given by the environment on employee performance through Motivation at Starbucks Coffee Cibubur is $0.823 \times 0.733=0.6043$. With these results, it can be concluded that the direct effect is smaller than the indirect effect, namely $0.179<0.6043$, so Motivation can be an intervening variable that mediates the effect of the work environment on the performance of employees at Starbucks Coffee Cibubur.

\section{Discussion}

\section{Influence of Work Environment on Employee Performance}

The first hypothesis (H1) in this study states that the work environment does not affect employee performance at Starbucks Coffee Cibubur. Based on the simple regression value, it proves that the work environment does not affect employee performance. This indicates that the work environment is still not suitable for maximizing employee performance. Based on the results of the t-test that has been carried out, it shows that $\mathrm{H} 1$ is rejected, and it can be concluded that the work environment does not affect employee performance. This is evident from the respondents' responses to the work environment variable on employee performance showing a low value. These results explain that the work environment factor is still not good enough for its employees, whereas if the work environment is adequate, it will significantly improve employee performance. A good working environment will affect the performance of its employees, and it can make a company can progress and develop following predetermined targets. The results of this study are not in line with research conducted byUmmah (2016), Wungkana (2015), Krisnayanti (2018), Ramadhani (2014), and Adrianto (2020) that the environment has a positive and significant effect on employee performance.

\section{The Effect of Motivation on Employee Performance}

The second hypothesis (H2) in this study states that motivation positively affects employee performance at Starbucks Coffee Cibubur Branch. The simple regression value proves that Motivation has a positive effect on employee performance; this indicates that if employee motivation is given correctly, employee performance will increase. This shows that $\mathrm{H} 2$ is accepted and it can be concluded that Motivation has a positive and significant effect on the performance of company employees at Starbucks Coffee Cibubur Branch. These results explain that the motivational factor has an important influence in improving employee performance. With the Motivation possessed by a person, it will affect the performance of each individual, it can make individuals get awards according to the 
performance achieved and for a company to progress and develop. The results of this study are in line with the research conductedHidayat (2015), Alamdani (2020), Sukadi (2021), and Badrianto (2019), with research results showing that Motivation affects employee performance.

\section{The Influence of Work Environment on Motivation}

The third hypothesis (H3) in this study states that the work environment positively affects motivation at Starbucks Coffee Cibubur Branch. Based on the simple regression value, it proves that the work environment has a positive effect on Motivation; this indicates that if the work environment is good, Motivation will also increase. This shows that $\mathrm{H} 3$ is accepted and it can be concluded that the work environment has a positive and significant effect on employee motivation at Starbucks Coffee Cibubur Branch. These results explain that work environment factors influence increasing Motivation. The results of this study are in line with research conducted by Saint (2018)

\section{The Influence of the Work Environment on Employee Performance Through Motivation}

Based on the intervening or mediation test results, the calculation obtained shows that the value of the indirect influence through Motivation is greater than the value of the direct influence of the work environment on employee performance. With these results, it can be concluded that the motivation variable can become a variable that mediates the influence of the work environment on the performance of employees at Starbucks Coffee Cibubur. This research is in line with previous research by Saint(2018).

\section{CONCLUSIONS}

\section{Conclusion}

Based on research and discussion regarding the employee performance of Starbucks Coffee Cibubur Branch is influenced by the work environment through Motivation, the authors conclude that: 1) The work environment does not affect the performance of Starbucks Coffee Cibubur employees. 2) There is an influence of Motivation on the performance of Starbucks Coffee Cibubur employees. 3) The influence of the work environment on the Motivation of Starbucks Coffee Cibubur employees. 4) The magnitude of the direct influence given by the work environment on the performance of Starbucks Coffee Cibubur employees is 0.179 , and the magnitude of the indirect effect given by the environment on employee performance through Motivation at Starbucks Coffee Cibubur is $0.823 \times 0.733=0.6043$. With these results, it can be concluded that the direct effect is smaller than the indirect effect, namely $0.179<0.6043$, then variable Motivation can be an intervening variable that mediates the effect of the work environment on the performance of employees at Starbucks Coffee Cibubur.

\section{Suggestion}

Suggestions submitted for Starbucks Coffee Cibubur Branch are 1) For companies: a). The work environment at Starbucks Coffee Cibubur Branch is still not good and 
structured neatly. Researchers suggest improving it again for the better. As always maintaining the tools for work, proper rest areas for employees, and other supporting facilities, the management of Starbucks coffee in the Cibubur branch is expected to continue to maintain and improve the employee's work environment because a good work environment will have a good influence on the performance of its employees. . It is also hoped that the management team will communicate more often with employees so that inputs and complaints can be conveyed. b). Providing good work motivation will increase employee performance because employees need motivational encouragement from themselves and others. So that work performance will be maximized, as well as the need for team management to conduct periodic surveys to increase the Motivation of their employees. c) Overall, it is expected to improve further and pay attention to the conditions of a good, safe, and comfortable working environment to produce maximum work results and continually motivate employees to maintain their enthusiasm at work. Thus, if the needs of employees are met in terms of the work environment and providing Motivation to employees, it will form a good and maximum work performance of employees, and the targets set by the company will be achieved. 2) For further researchers; In order to carry out further research that is more specific in addition to factors of the work environment, employee motivation, and performance so that it can broadly generalize several influences that can contribute to employee performance or with new variables following developments and add broader insights.

\section{BIBLIOGRAPHY}

Adrianto, Teddy. 2020. The Influence of Work Environment and Motivation on Employee Performance in Wood Factory. International Journal of Economics, Business and Accounting Research (IJEBAR) Peer Reviewed - International Journal Vol-4, Issue1, 2020 (IJEBAR)

Afandi, P. 2018. Manajemen Sumber Daya Manusia (Teori, Konsep dan Indikator). Riau: Zanafa Publishing.

Almadani, Sultan Alam. 2020. Influence of Work Environment, Employee Motivation and Performance Employee on Pandemic Situation in Indonesia, Economics and Business Faculty Student, Universitas Mercu Buana, Jakarta Indonesia, Associate Professor, Universitas Mercu Buana, Jakarta Indonesia.

Badrinath, Yuan. 2019. The Effect of Work Environment and Motivation on Employee Performance of PT, Journal of Research in Business, Economics, and Education. Volume 1 Issue 125 Oct 2019.

Farida, Umi dan Hartono, Sri. 2016. Manajemen Sumber Daya Manusia II. Ponorogo: Umpo Ponorogo Press.

Hasibuan, Malayu S. P. 2016. Manajemen : Dasar, Pengertian, dan Masalah, Edisi Revisi. Jakarta: Bumi Aksara.

Hidayat, Zainul. 2012. Pengaruh Lingkungan Kerja dan Disiplin Kerja Serta Motivasi Kerja Terhadap Kinerja Karyawan Perusahaan. Jurnal WIGA. Vol. 2 No. 1, Maret 2012. 
Kasmir. 2016. Manajemen Sumber Daya Manusia (Teori dan Praktik). Depok: PT Rajagrafindo Persada.

Krisnayanti, Putu Natalia. 2018. Pengaruh Kompensasi, Motivasi dan Lingkungan Kerja Terhadap Kinerja Karyawan PT. Delta Satria Dewata Denpasar. E-Jurnal Manajemen Unud.

Luthans, Fred. 2011. Perilaku organisasi. Yogayakarta : Andi

Moeheriono. 2012. Pengukuran Kinerja Berbasis Kompetensi. Jakarta: Raja Grafindo Persada.

Narasuci, Win. 2018. Effect of Work Environment on Lecturer Performance Mediated By Work Motivation and Job Satisfaction. Journal of Applied Management (JAM) Volume 16 Number 4, December 2018

Ramadhani, Arsy. 2014. Effect of Work Environment, Work Motivation, and Work Discipline on Employee Performance. Vol.VI No.1 Januari 2014 Jurnal Tepak Manajemen.

Robbins, Stephen. 2015, Perilaku Organisasi, Jakarta: Penerbit Salemba Empat.

Sarwono, Jonathan, 2010. Analisa Jalur Untuk Riset Bisnis Dengan SPSS. Yogyakarta: Andi

Sedarmayanti. 2017. Manajemen Sumber Daya Manusia : Reformasi Birokrasi dan Manajemen Pegawai Negeri Sipil. Bandung: PT Refika Aditama.

Sugiyono. 2018. Metode Penelitian Bisnis: Pendekatan Kuantitatif, Kualitatif, Kombinasi, dan $R \& D$. Bandung: Alfabeta.

Sukardi. 2021. The Effect of Work Environment, Work Discipline and Work Motivation on Employee Performance of Kayu Aro Barat Sub District Office. SSRG International Journal of Economics and Management Studies 7.8 (2020): 41-44

Sunyoto, Danang. 2015. Manajemen dan Pengembangan Sumber Daya Manusia. Yogyakarta: Center for Academic Publishing Service.

Sinambela, Lijan Poltak. 2018. Manajemen Sumber Daya Manusia. Jakarta: PT Bumi Aksara.

Umam Mohammad Hairul. 2016. Pengaruh Lingkungan Kerja dan Motivasi Terhadap Kinerja Karyawan (Studi Pada Karyawan PT. PLN (Persero) Pelayanan dan Jaringan Area Situbondo). Jurnal Administrasi Bisnis (JAB)|Vol. 40 No.2 November 2016

Winardi. 2016.Kepemimpinan dalam Manajemen. Jakarta: PT. Rineka Cipta.

Wungkana, Winda. 2015. Pengaruh Lingkungan Kerja, Motivasi dan Pengembangan Karir Terhadap Kinerja Karyawan PT. Telkom Manado. Jurnal Berkala Ilmiah Efisiensi Volume 15 No. 05 Tahun 2015. 